\title{
ANALYSIS OF THE APPLICATION OF INFORMATION AND COMMUNICATION TECHNOLOGY (ICT) ON SCHOOL RECORD-KEEPING, IN SECONDARY SCHOOLS IN BENIN CITY, NIGERIA
}

\author{
Imasuen Kennedy and Dr. (Mrs.) P. M. Abinuomo
}

Institute of Education, University of Benin, Benin City, Nigeria

Email: kennedy.imasuen@uniben.edu,modukpe.abinuomo@uniben.edu

Cite this article:

Imasuen K., Abinuomo P.M. (2022), Analysis of the Application of Information and Communication

Technology (ICT) on School Record-Keeping, in Secondary Schools in Benin City,

Nigeria. British Journal of Computer, Networking and Information Technology 5(1), 1-10. DOI:

10.52589/BJCNIT-

MWCMJKCY

\section{Manuscript History}

Received: 29 Dec 2021

Accepted: 25 Jan 2021

Published: 3 Feb 2022

Copyright $(92022$ The Author(s). This is an Open Access article distributed under the terms of Creative Commons AttributionNonCommercial-NoDerivatives 4.0 International (CC BY-NC-ND 4.0 ), which permits anyone to share, use, reproduce and redistribute in any medium, provided the original author and source are credited.
ABSTRACT: Record-keeping in every organization including the educational system is a vital tool in school administration. It is indispensable since it plays a role in the day to day running of the school. However, the ICT facilities are not used effectively even though most schools have invested heavily in them. It is in the light of the above that this study sought to examine the role of ICT application on school record-keeping in secondary schools in Benin City, Edo State. Two research questions were raised to guide the study. The study adopted a descriptive research design. The population of the study consisted of all the public and private secondary schools in Benin City. The sample for the study consisted of eight hundred (800) respondents. The research instrument for the study was a structured questionnaire. The data collected were analyzed using mean and standard deviation. The findings that emanate from the study revealed that the level of ICT application in school record keeping in public and private secondary schools in Benin City, Edo State was to a low degree, and the prevalent record-keeping facilities were: attendance register, admission register, scheme of work, school time table, lesson notes, individual pupil's files, and staff movement book. It, therefore, recommended that Government and other education stakeholders should invest in ICT applications for school management and record keeping.

KEYWORDS: Records, Information Communication Technology, Record Keeping, Application 


\section{INTRODUCTION}

In any educational institution, education records form a background against which decisions about an individual student's status or progress are made. Educational record-keeping practices, however, vary substantially by the size of the institution and sophistication of administrative practice. They also vary as students move along the continuum from pre-school towards post-graduate education because the role of educational institutions varies along the same continuum.

Record keeping in every organization including the educational system is a vital tool in school administration. It is indispensable since it plays a role in the day to day running of the school. For decisions that affect the daily operation of the school to be effectively carried out, school administrators rely on the information that is captured on records. It is an impossible task to plan and administer any organization where records are not kept or are carelessly and fraudulently kept. According to Koko and Nwiyi (2004), records are information banks establishing what had been done or known, what is to be done and how things are to be carried out. More so, they provide a useful wealth of information not only for the school but also for the larger community. Without record keeping knowledge, the learning world would be hampered.

The American Heritage Dictionary cited by Onifade (2004), defined records as information or data collected and presented on a particular subject. By implication, any processed or unprocessed datum that is collected and kept for future use constitutes a record. School records are, therefore, information or data which are collected on various aspects of a school and preserved for future use. The information or data which are written manually or electronically are preserved in books, file diskettes, flash drives and other electronic materials. Aloyslies, et al, (2014) summarized this concept when they stated that school records include all books and files containing information on what went on in a school, who was in the school and the type of properties owned by the school.

Oleboye (2004) posited that school records include: register of admission and withdrawal, register of attendance, logbook, cash book, visitors' book, copy of education law, scheme of work, teacher's record of work, school time-table, corporal punishment book, school diary, and minutes book of the board of studies/governor. Others are National Policy on Education, Examination record book (C.A. Booklet), Syllabus, Time/movement register, staff files, individual pupil's files, discipline enforcement book, lesson notes, Examination result record (JSS, WAEC, NECO,), Advisory Board meeting book, Parent Teachers Association (PTA), correspondence file, receipts, and cash book,

School records serve as a bank where information is kept with the hope of retrieving it for utilization. Proper keeping of school records could enhance a planning process, serve as historical records, provide knowledge on students' academic performance and facilitate schools' financial administration. It will also provide a basis for advisory and counselling services. School records provide raw data which can be used by officials of education ministries for planning purposes. Data collected from school records on pupils' enrolment and school facilities can be analyzed in order to determine the number of teachers and other resources that would be needed by the school. Within the school, records will enhance planning for the placement of students into higher classes and serve as a historical source of useful information to a principal or a headmaster's successor and outside researchers. 
School records also enable one to know the termly and yearly academic performance of students. School managers are able to determine the academic progress of the students and take necessary precautionary measures towards improving their academic performance. The financial status of the school could be determined through school records. Income and expenditure of the school are entered into an appropriate ledger, and this enhances accountability on the part of the school administrator. School records also provide a basis for advisory and counselling services. Teachers, headteachers and school counsellors could make use of records in order to get advice on students' academic activities.

A school record serves the major purpose of assisting in the effective management of the school. Principals are required to keep records not only because it is a statutory duty but because of their value in improving management practices. Since the school is a formal organization, there is the need for accurate, timely, sufficient and relevant information which is kept in the form of records since they provide information on past, present and future activities of the school. The traditional method of gathering, processing, preserving and presenting/disseminating large volumes of information in print media has failed capacity to total loss of important information.

Information and Communication Technology (ICT) refers to forms of technology that are used to transmit, store, create, share or exchange information. Information Communication Technology is the fusion of two technologies, information technology (IT) and communication technology (CT) (Iwu, 2006). ICT embraces all technologies for manipulative communication such as radio, television, etc, and technology for communication through voice and sound or images using a microphone, camera, loudspeaker and telephones/mobile phones, (Osu et al,2010). Information and Communication Technologies (ICTs) are indispensable and have been accepted as part of the contemporary world, especially in industrialized societies, to the extent of giving a new phase to the educational system in terms of pedagogical approach (Ololube,2006).

Fari (2010), described information and communication technology facilities as all the facilities available for the identification, generation, processing, storage, packaging, preservation and transfer of information, regardless of time and distance constraints. In other words, information and communication technologies are information handling tools used for producing, storing, processing, distributing and exchanging information. Today, it is an increasingly powerful tool for participating in global markets that promote political accountability, improve the delivery of basic services and enhance local development opportunities (UNDP, 2006). ICT facilities influence and affect people's private and corporate work lives in one way or the other, and encompass technology, socialization, politics, economics and education for global transformation.

The Federal Ministry of Education (2010) identified the role of ICT policy on education, amongst others, as providing the needed guidance on what is expected in the entire process of ICT integration in and to all stakeholders in education. Its implementation, therefore, should lead to a speedy transformation of the teaching, learning and administration of education.

Information and Communication Technology (ICT) has caused a major paradigm shift in how we approach the gathering, storage, retrieval and analysis of information in every industry. ICT is becoming increasingly used in schools and educational institutions and has been established in professional and classroom practice. What is clear is that any ICT implementation needs to 
address management problems such as delays in decision-making, communication barriers and time-wasting in completing tasks in the required time. But this has not been the case simply because the school administrators have not realized the importance of using ICT in managing secondary schools.

ICT and school management are important issues since it is well known that senior managers in schools have a major impact on classroom and curriculum practices and that the use of ICT in schools permeates aspects of school practice to the extent that it impacts the practice of all staff and school activities at large (Passey, 2002). Many ICT tools such as computers and the internet are used in teaching and evaluating students in the classroom but not in administration and management.

The available information systems designed for the purpose of improving school management include reporting systems, monitoring and tracking systems, parental alert software, development planning, business management, timetabling and communications. All these, if used properly, can result in education development. Management of secondary schools using ICT ensures the efficiency of administration and organization of the school.

In a study carried out by Abdallah (2009) in Uganda, it was revealed that many secondary schools had weaknesses in the management of such aspects yet they had ICT facilities that could enhance effective management if they were used effectively. Evidence showed that many secondary schools in Edo State have ICT tools such as computer internet and databases which they used for other purposes such as teaching and evaluation, typing and printing examination papers. But such tools had not been fully utilized to manage school activities. ICT can enhance school management in terms of assisting managers (school principals) in organizing, planning, implementing, monitoring and evaluating school operations (Eremu, 2007).

Victoria (2002) asserted that ICT provided the means for communicating financial information to the governing body (administration) to help them in making decisions on the use of financial software, thereby giving the bursar a good indication of the direction of the business at school and the means of comparing data with previous months, terms and years (Gbenga, 2003). This gives a baseline for effective decision making, say about how fees should be collected, how salaries should be paid and how to carry out other procurement services in the school. In the opinion of Gbenga (2003), the use of ICT, for accounting purposes needed standard installed software on interlinked computers where all transactions could be automatically logged on the computer to assist in fee payments and payroll procurement.

Consequently, ICT has become indispensable in the administration of schools. Lawal (2001) stated that it was no longer fashionable for a secretariat staff to write all letters and prepare all other documents by hand or by the use of a typewriter. Essentially, the following are the ICT facilities that are commonly used in an ideal office: computer printer; internet services; photocopying machine; satellite disc flash drives; laptops and other electronic devices.

The effect of ICT in school record keeping cannot be denied as typing of letters and schemes of work and document filing could be time consuming and tedious. Nwosu (2003) noted that ICT assisted the school principal to meet the task of school management in the area of recordkeeping. In view of the human factor involved, information or data which are written manually would often invariably result in error or arrears of work, thus giving room to misleading variables of decision-making as well as making information retrieval difficult. But with the use 
of ICT, speed, accuracy, quick information retrieval and decision making can take place. Adegun (2002) argued that the introduction of ICT in school enhanced the daily school routine, input and output facilities which facilitated interrogation of files alterations, displays and retrieval of information which were not possible with the manual system. Definitely, the school principal needs the assistance of ICT equipment such as the computer to neatly produce his documents, reproduce and keep them for future use. From here, it is clear that the ability of the school head to effectively plan and manage his school nowadays is enhanced through the use of ICT application/equipment for recording keeping. ICT serves as a necessary aid to the principal in the area of record-keeping because of the advantages it offers (Awoyokun, 2009). ICT facilities make it easy to store documents and retrieve them when they are required, aid the production of school documents, time-tables, schemes of work, reports. It promotes the accuracy and prompt delivery of services, for instance, the school rules and regulations could be produced and given out to students on their admission into the school, and an ICT facility saves labour and also reduces time spent on the job.

Other reasons for the utilization of ICT in record-keeping, according to Eynon (2006) are that it aids school administration in the speed of doing things because of the high number of student's enrolment in schools and the many jobs they needed to perform. The use of ICT can be virtually or physically, thus providing scholars with easier access to information. Odufuma (2006) averred that ICTs were used in school's management because they helped school managers to cope with information explosion handling and processing with greater speed and accuracy than the manual method.

Information and Communication Technology (ICT) has caused a major paradigm shift in how we approach the gathering, storage, retrieval and analysis of information in every industry.

Information Technology (IT) with the global use of computers and other internet facilities has gone a long way in improving our record-keeping system in schools and institutions. It is stipulated that information be kept in accordance with the education law and be produced on request by the agents of education on official inspection. Teachers' service manual (1990) makes it mandatory for schools to keep the statutory records such as Admission register, logbook, a copy of the National Policy on Education, attendance register, school timetable, diary of works, visitor's book, examination record book and movement/time book. On the other hand, there are non-statutory records that are created for the purpose of administrative convenience. Such records are health record book, school calendar, PTA records/account book stock book, inventory book and staff meeting minutes book

The available information system designed for the purpose of improving school management and record-keeping includes reporting systems, monitoring and tracking systems, parental alert software, development planning, business management, timetabling and communications, all of which, if used properly, can result in education development in Nigeria in general and Edo State in particular. In Benin City, school administrators in Edo State have seen the incorporation of ICT facilities into the management of their school's records and the administrations uses, management information systems like salary, results and registry management system, fee tracking records and payment system to assist in record keeping and examination and financial management of the schools. (Tibagye, 2000). However, the ICT facilities are not used effectively simply because most schools have invested heavily in them. Teachers and school managers seem to lack the required skills to use the ICT applications in 
the management of school records and have, therefore, not realized their role in managing basic education in secondary schools in Benin City, Edo State.

It is in the light of the above that this study sought to examine the role of ICT application on school record-keeping in secondary schools in Benin City, Edo State.

\section{Research Questions}

The following research questions were raised to guide the study.

1. What is the level of ICT applications in school record-keeping in Edo State?

2. What are the prevalent record-keeping techniques in public and private secondary schools in Benin City, Edo State?

\section{Methods}

The study adopted a descriptive research design. The population of the study consisted of all the public and private secondary schools in Benin City. Benin City has 75 public secondary schools and over 200 private schools. Twenty (20) public and 80 private secondary schools were randomly selected. The respondents were the principals, bursars and one form or class teachers in each of the one hundred schools selected. The sample for the study consisted of eight hundred (800) respondents which were 100 principals, 100 bursars and one form teacher from secondary schools in Benin Metropolis. The form teachers were conveniently selected from both the public and private secondary schools in Benin City.

The research instrument for the study was a structured questionnaire titled, "ICT Application and Record-Keeping Questionnaire" (IARKQ). It was divided into sections. Section A elicited bio-data information which consisted of the name of the school, location, size of school sex and ownership of school from the respondents. Section B was meant to find out the extent to which ICT applications were used on school records. Section C sought to find out school records prevalent in schools. The questionnaire was validated by three experts in the field of ICT and record keeping. The reliability of the questionnaire was ascertained using the Cronbach reliability statistics. 50 copies of the instrument were administered to respondents in schools not selected for the study in Benin City. It gave an alpha value of 0.89 The data collected were analyzed using mean and standard deviation. A criterion mean of 2.50 was used for acceptance 


\section{RESULTS}

Table 1: Level of ICT application in school record keeping in public and private secondary schools in Benin City, Edo State

\begin{tabular}{lccl}
\hline ICT facilities & Mean & Standard deviation & Remarks \\
\hline Computers & 2.79 & 0.72 & Occasionally used \\
Printers & 2.17 & 0.78 & Rarely used \\
Photocopiers & 2.35 & 0.79 & Rarely used \\
Flash drives & 2.04 & 0.75 & Rarely used \\
Laptops & 2.48 & 0.74 & Rarely used \\
Compact discs & 2.43 & 0.85 & Rarely used \\
Memory cards & 2.97 & 0.85 & Occasionally used \\
Handsets & 3.53 & 0.77 & Frequently used \\
Scanners & 1.97 & 0.7 & Rarely used \\
Email & 2.36 & 0.87 & Rarely used \\
Cluster & $\mathbf{1 8 . 0 3}$ & $\mathbf{4 . 9 9}$ & \\
\hline
\end{tabular}

Table 2 shows that the respondents frequently use phones, occasionally use computers and memory cards. They rarely used printers, photocopiers, flash drives, laptops, compact discs, scanners, and email. The cluster mean of 18.03 and standard deviation of 4.99 implies that the level of ICT application in school record keeping in public and private secondary schools in Benin City, Edo State was to a low degree.

Table 2: School records prevalent in school management in basic education in Benin Metropolis Local Government Area of Edo State

\begin{tabular}{llll}
\hline ICT facilities & Mean & Standard deviation & Remarks \\
\hline Admission register & 2.63 & 0.51 & Available \\
Attendance register & 2.64 & 0.69 & Available \\
Log-book & 2.44 & 1.17 & Not available \\
Cash-book & 2.31 & 1.38 & Not available \\
A copy of education law & 2.28 & 1.41 & Not available \\
Scheme of work & 2.59 & 0.78 & Available \\
School time table & 2.57 & 0.84 & Available \\
Corporate punishment book & 2.17 & 1.41 & Not available \\
Minutes book & 2.41 & 1.17 & Not available \\
Teachers record of work & 2.48 & 1.05 & Not available \\
Visitor book & 2.31 & 1.35 & Not available \\
Staff movement book & 2.59 & 0.75 & Available \\
National Policy on Education & 2.40 & 1.20 & Not available \\
Examination record book (C.A Booklet) & 2.48 & 1.05 & Not available \\
Syllabus & 2.51 & 0.80 & Available \\
Receipts & 2.41 & 1.17 & Not available \\
PTA notebook & 2.44 & 1.11 & Not available \\
Lesson notes & 2.52 & 0.93 & Available
\end{tabular}




\begin{tabular}{llll}
\hline & 2.41 & 1.20 & Not available \\
Staff files & 2.51 & 0.99 & Available \\
Individual pupil's files & 2.37 & 1.23 & Not available \\
Health records/factor & 2.20 & 1.56 & Not available \\
Others & & & \\
\hline
\end{tabular}

Table 2 shows the ICT facilities prevalent in school record keeping in public and private secondary schools in Benin City, Edo State. It further showed that the respondents agreed that the attendance register, admission register, scheme of work, school timetable, lesson notes, individual pupil's files, and staff movement book were available in the schools for recordkeeping. However, examination record book, teachers' record of works, PTA notebook, logbook, minutes book, receipts, staff files, National Policy on Education, health records/factor, visitors book, cash book, a copy of education law, corporate punishment book and others were not available.

\section{DISCUSSIONS}

The study that the level of ICT application in school record keeping in public and private secondary schools in Benin City, Edo State was to a low degree. This low degree could be attributed to the challenges that the teachers faced in order to assess these ICT facilities. The study also revealed that the ICT facilities such as computers, printers, photocopiers, flash drives, laptops, compact discs, memory cards, headsets, scanners and emails were used occasionally in the keeping of records in public and private secondary schools in Benin City, Edo State. This showed that school managers such as the principals, bursars and teachers did not always use or rarely used all the above-mentioned ICT facilities for the management of schools in their domain. The findings agreed with Abdallah (2009), who posited that many secondary schools had weaknesses in the keeping of school records with ICT even when such facilities that would enhance effective management if they were used effectively are available.

The study also showed that attendance register, admission register, scheme of work, school timetable, lesson notes, individual pupil's file and staff movement book were available while others such as examination record book, teacher's record of work and PTA notebook and many more were not available. The findings could be explained by the fact that attendance register, admission register and scheme of work and statutory records that kept by law and must be produced on request by supervisors, inspectors and ministry of education officials. The finding is in line with Adegun (2002) who argued that the introduction of ICT in school enhanced daily school routine, the input and output facilities which facilitated interrogation of file alterations and displays and retrieval of information which were not possible with the manual system. He further added that the school principal needed the assistance of ICT equipment such as the computer to neatly produce, reproduce and keep his document for future use. The findings aligned with the assertion of Odufuma (2006) that ICTs, especially computers were used in school record keeping because they helped school managers to cope with information, explosion, handling and processing with greater speed and accuracy than the manual method. 


\section{CONCLUSION}

The study concluded that ICT applications were used occasionally in the management of school records in Benin City, Edo State. This made its application to be low among the managers of the school. Also, the attendance register, admission register and many more were the recordkeeping prevalent in school. It is pertinent that ICT applications and facilities should be effectively used for students' record keeping and proper school management. More ICT applications and facilities should be procured by the government and sent to schools as per student population that will make large schools have more ICT applications than small schools. Government and other education stakeholders should invest in ICT applications for school management and record keeping. School managers such as principals, bursars and teachers should be encouraged to use ICT applications for students' record-keeping and school management. This will make for efficiency in the system.

\section{REFERENCES}

Abdallah, T (2009). The role of Information and Communication Technology in the management of selected secondary schools in central Uganda. M. Ed project in Makerere University. Retrieved from https;//www.researchgate.net/publication.Accessed 6th August 2018.

Adegun O.A (2002) Communication and Administration Effectiveness of principals of secondary schools in South-Western Nigeria. Unpublished PhD Thesis. University of Ado Ekiti Nig.

Aloysius, S. N, Akpabio I. U \& Sammy, M. E (2014). Utilization of ICT for school Record Keeping. A strategy for principals' management of secondary schools in Akwa Ibom State, Nigeria. Multidisciplinary Journal of Research Development vol.22 No1.

Awayokun, A.A (2007) Business studies BK2, Ibadan. Macmillan Publishers Ltd.

Eremu J. (2007). ICT connectively in school in Uganda. Retrieved 06 August 2018 from http://:www.iconnect.online.org

Eynon, R. (2006). The use of ICTS for Teaching and Learning in Law Education some innovators Perspection Accessed 07/08/2018 from http://webcli.ncl.ac.uk/2006/issues3/eynon3.htm.

Fari, S.A (2010) "Information sharing on teaching and Research in Tertiary Institutions in Katsina state. Samaru Journal of Information Studies: 10 (1 \&2). Pp 12-16

Gbenga, S (2003). African Youth and the Information Society: What role does ICT play in the business?

Iwu, A.O. (2006). Information and Communication Technology in A.O. Iwu, Ike, Clumezee, O.S. (Eds.) Perspective in Education Technology (pp33-35).Quern. (M Peace Publisher

Nwosu, A.A (2003). Integrating ICT into STM Classroom: states and Implication Proceeding of the 44th STAN conference, 0 pp 58-60.

Odufuwa, S. (2006).ICT as a Research tool in Libraries. Nigerbblies, 17(1\&2), 100-115

Olagbofe, A.A (2004). Introduction to Educational Management in Nigeria.Ibadan Daily Graphics (Nig) Ltd.

Olotube, N. P. (2006) "Appraising the Relationship between ICT usage and integration and the standard of teacher education program in developing economy. International Journal of Education and Development using ICT. 2(3) 
Osu, S.R. Udosen, I.R. \&Akpan B.P. (2010). Application of ICT in Senior Secondary Biology Teachers. Journal of Educational Research and Policies: 50) 22-25 Ramalho C.P (2006). The Educational Role of the Information and Communication Technologies (ICT) is a study of an intervention in Portuguese, a Basic level school. UNDP (2006). Information Communication Technologies and Development Available at http://usbdng.undp.fig.it4dev/accessed 31st July 2018

Victoria, L.T (2002). "Survey of Information and Communication Technology. Utilization in Philippine Public High Schools" Formation for Information Technology Education and Development (FIT-ED 